\title{
O DIREITO À EDUCAÇÃO NO ORDENAMENTO JURÍDICO BRASILEIRO: A HISTÓRICA NEGAÇÃO DO DIREITO
}

\author{
THE RIGHT TO EDUCATION IN THE BRAZILIAN LEGAL ORDINATION: THE \\ HISTORICAL DENIAL OF THE RIGHT
}

\section{EL DERECHO A LA EDUCACIÓN EN LA ORDENACIÓN JURÍDICA BRASILEÑA: LA NEGACIÓN HISTÓRICA DEL DERECHO}

\author{
Vanessa Campos de Lara Jakimiu \\ E-mail: vanessajakimiu@yahoo.com.br \\ Universidade Estadual do Paraná - UNESPAR / União da Vitória - PR
}

\begin{abstract}
RESUMO
O presente estudo apresenta teorizações concernentes à legislação educacional brasileira tomando como objeto de estudo as constituições federais brasileiras e as legislações infraconstitucionais e tem como objetivo investigar como ocorre a declaração do direito à educação nestes documentos normativos. Metodologicamente o estudo adota os moldes da pesquisa documental. Em sua estrutura o estudo está organizado a partir de períodos históricos demarcados pela exaração das constituições federais brasileiras. Do estudo empreendido é possível constatar que a educação no Brasil se consolidou a partir da histórica negação do direito, já que o país passou mais tempo negando este direito e/ou o restringindo-o à determinadas pessoas e classes do que o declarando como direito público e universal.
\end{abstract}

PALAVRAS-CHAVE: Educação. Políticas Educacionais. Direito à Educação.

\section{ABSTRACT}

The present study presents theorizations concerning the Brazilian educational legislation taking as object of study the Brazilian federal constitutions and the infra-constitutional legislation and aims to investigate how the declaration of the right to education occurs in these normative documents. Methodologically, the study adopts the molds of documentary research. In its structure, the study is organized from historical periods demarcated by the statement of the Brazilian federal constitutions. From the study undertaken, it can be seen that education in Brazil was consolidated from the historical denial of the right, since the country spent more time denying this right and / or restricting it to certain people and classes than declaring it as a public right. and universal.

KEYWORDS: Education. Educational Policies. Right to education.

\section{RESUMEN}

El presente estudio presenta teorizaciones sobre la legislación educativa brasileña tomando como objeto de estudio las constituciones federales brasileñas y la legislación infraconstitucional y tiene como objetivo investigar cómo se produce la declaración del derecho a la educación en estos documentos normativos. Metodológicamente, el estudio adopta los moldes de la investigación documental. En su estructura, el estudio está organizado a partir de períodos históricos demarcados por la declaración de las constituciones federales brasileñas. Del estudio realizado, se puede ver que la educación en Brasil se consolidó a partir de la negación histórica del derecho, ya que el país pasó más tiempo negando este derecho y/o restringiéndolo a ciertas personas y clases que declarándolo como un derecho público y universal.

PALABRAS-CLAVE: Educación. Políticas educativas. Derecho a la educación. 


\section{INTRODUÇÃO}

O presente estudo apresenta teorizações concernentes à legislação educacional brasileira tomando como objeto de estudo as constituições federais brasileiras e as legislações infraconstitucionais. A Constituição Federal é a lei fundamental que rege o país, situando-se hierarquicamente como a mais alta disposição legal no âmbito do ordenamento jurídico, e, portanto, orienta a exaração de todas as demais legislações brasileiras.

Ao longo de sua trajetória histórica, o país passou por sete Constituições Federais até chegar na atual Constituição que rege o país e considerando esta trajetória histórica o presente estudo tem como objetivo investigar como ocorre a declaração do direito à educação nestes documentos normativos e em todos os demais versem sobre esta questão.

Metodologicamente o estudo adota os moldes da pesquisa documental, a qual tendo como base empírica o documento escrito, permite a investigação da atividade humana em uma determinada época:

[...] o documento escrito constitui, portanto, uma fonte extremamente preciosa para todo pesquisador nas ciências sociais. Ele é, evidentemente, insubstituível em qualquer reconstituição referente a um passado relativamente distante, pois não é raro que ele represente a quase totalidade dos vestígios da atividade humana em determinadas épocas. Além disso, muito frequentemente, ele permanece como o único testemunho de atividades particulares ocorridas num passado recente. (CELLARD, 2008, p. 295).

A base empírica da investigação demarcada pela análise de documentos de fontes escritas públicas contemporâneas (MARCONI; LAKATOS, 1999) contemplando a legislação concernente ao direito à educação no Brasil, mais especificamente das Constituições Federais de 1824, 1891, 1934, 1937, 1946, 1967 (EC 1/1969) e 1988 (EC 59/2009) e das leis que normatizam a educação brasileira lei 4.024/61, lei 5.692/7, lei 8.069/1990, lei 9.394/96, lei $11.494 / 1996$ e lei $11.274 / 2006$.

Em sua estrutura o estudo está organizado a partir de períodos históricos demarcados pela exaração das Constituições Federais brasileiras sendo precedido em cada seção de análise das leis que versem sobre a declaração do direito à educação. 


\section{A DECLARAÇÃo DO DIREITO À EDUCAÇÃO NA CONSTITUIÇÃo FEDERAL DE 1824}

Os primeiros registros de educação formal na história brasileira estão associados ao Brasil Colônia. Os jesuítas sob as determinações da coroa portuguesa permaneceram no país de 1549 a 1759 ministrando ensino de cunho religioso nos colégios jesuíticos. Importa observar que neste contexto histórico o ensino era destinado apenas aos homens. As mulheres eram excluídas "[...] do sistema escolar estabelecido na colônia. Podiam, quando muito, educar-se na catequese.

Estavam destinadas ao lar: casamento e trabalhos domésticos, cantos e orações, controle de pais e maridos." (STAMATTO, 2011, p. 2).

Esse contexto que só vai se modificar quando o Marquês de Pombal expulsa os jesuítas e implementa a reforma educacional conhecida como Reforma Pombalina. A Reforma Pombalina retira a educação das mãos da igreja e a transfere para o Estado.

A reforma pombalina implementa as aulas régias fundamentadas no ensino público e laico passando a atender o público feminino, porém, mantendo a separação por sexo, “[...] ou seja, somente professoras mulheres podiam dar aulas às meninas e professores homens aos meninos e nunca as meninas estariam ao lado dos meninos na mesma sala de aula." (STAMATTO, 2011, p. 3).

Na prática a Reforma Pombalina ficou marcada pela destruição do único modelo de educação sistematizado até então existente no país. Do ponto de vista da prática pedagógica, porém, o ensino jesuítico permaneceu tangencialmente já que os professores que ministravam o "novo" ensino haviam sido formados pelos colégios jesuíticos. Além disso, a reforma não representou na prática "[...] um ensino extensivo a toda população, muito menos às mulheres [...].” (STAMATTO, 2011, p. 4).

No ano de 1808 ocorre a vinda da família real portuguesa e sua corte para o Brasil e no ano de 1823, após a Proclamação da Independência do Brasil ocorrida em 7 de setembro de 1822, buscava-se instituir formalmente o novo Estado Nacional que passava de colônia sem autonomia política e econômica vinculada à Portugal para um país independente. Para tal, foi organizada uma Assembleia Constituinte com o intuito de implementar a primeira Constituição do país. No entanto, tendo em vista as divergências políticas entre dois projetos, um de cunho liberal (Projeto de Antonio Carlos) e outro de cunho absolutista (D. Pedro I), D. Pedro I dissolve a constituinte e redige o texto constitucional contando com um conselho instituído por dez 
juristas de sua confiança resultando na primeira constituição brasileira promulgada em 25 de março de 1824.

Do ponto de vista da organização política, a Constituição Política de 1824 cria o poder moderador que hierarquicamente estava acima dos três poderes (Executivo, Legislativo e Judiciário).

O caráter liberal da CF de 1824 resolve as questões políticas, uma vez que atende à uma determinada parcela da sociedade que encontrava resistência para instituir a produção capitalista e industrializante em um Estado imperial escravagista e que repudiava qualquer intento neste sentido e ao mesmo tempo atendia as demandas das negociações internacionais. O conteúdo liberal da Constituição Federal de 1824, portanto, não afetava as relações sociais escravagistas que estavam na base econômica do país, pelo contrário, "[...] acabavam por legitimar essas mesmas relações por intermédio da adoção do direito de propriedade privada pleno como um direito fundamental dos proprietários, inclusive sobre seres humanos tidos como escravos." (MEZZAROBA; CASTRO, 2017, p. 10).

No que se refere especificamente à educação, no título $8^{\circ}$ "Das Disposições Gerais e Garantias dos Direitos Civis e Políticos dos Cidadãos Brasileiros”, o artigo 179 prevê a inviolabilidade dos direitos civis e políticos garantindo a instrução primária e gratuita a todos os cidadãos. (BRASIL, CF, 1824).

No entanto, de acordo com o ideário explorado por Ferraro (2008) embora pudesse parecer generosa para o seu tempo, a CF de 1824 entra em contradição com as condições reais para sua efetivação, já que as escolas primárias gratuitas eram quase inexistentes na época. Além disso, a educação gratuita para todos os cidadãos prevista na CF de 1824, no contexto histórico e social brasileiro de escravidão ${ }^{1}$ na verdade era uma educação destinada apenas para quem era considerado cidadão e os escravos não eram considerados cidadãos pela referida constituição.

\footnotetext{
${ }^{1}$ A escravidão teve início em 1538 e teve legalmente seu fim em 1888 por meio da lei imperial 3.353 sancionada em 13 de maio. Esta lei foi promulgada a partir do tensionamento provocado pelos movimentos de resistência do povo negro escravizado e fortalecido pelos movimentos abolicionistas e, sobretudo, pelo constrangimento advindo de pressões internacionais já que o Brasil foi o último país a abolir a escravidão no mundo. Maior detalhamento ver: BECKLES (2003). Cabe salientar que embora tenha havido a declaração do direito, a liberdade das pessoas negras escravizadas não foi implementada de forma imediata/linear e ocorre sem qualquer tipo de reparação histórica mantendo-se as marcas patrimoniais e escravagistas que sustentavam a consolidação do país.
} 
Nesta época, a igreja católica atuava catequizando a população pela palavra e a questão da obrigatoriedade não era prioridade uma vez que uma sociedade fundada no trabalho escravo não demandava de pessoas instruídas. (CURY; FERREIRA, 2010).

O preceito da educação gratuita e para todos os cidadãos também esbarrava na questão do financiamento já que a Constituição é totalmente omissa com relação ao financiamento não prevendo meios para a consecução desse direito. (VIEIRA; VIDAL, 2015).

Em 1827 é promulgada a lei que manda criar escolas de primeiras letras em todas as cidades, vilas e lugares mais populosos do Império. Esta lei, no entendimento de Stamatto (2011, p.5), embora padronize as escolas das primeiras letras é claramente discriminatória com relação ao ensino da mulher. De acordo com a referida lei as mulheres não deveriam aprender "[...] todas as matérias ensinadas aos meninos, principalmente as consideradas mais racionais como a geometria, e em compensação deveriam aprender as 'artes do lar', as prendas domésticas."

Flach (2009, p. 504) explica que a educação nos primeiros anos de República mantevese sem alterações. O ensino elementar ficou sob a responsabilidade dos Estados "[...] dentro de suas possibilidades financeiras. Entregues à própria sorte, os Estados passaram a organizar sistemas independentes, o que contribuiu para uma completa desorganização quanto à garantia do direito à educação para a população.”

Após quase quatro séculos de Império Português no país a CF de 1824 apresenta poucos avanços. Neste contexto histórico, existiam apenas algumas escolas primárias e o ensino posterior $^{2}$ organizava-se a partir de aulas avulsas. Ou seja, embora a constituição previsse a educação como direito isto não ocorreu na prática. “Assim, à população em geral restava - [...] - conseguir alcançar os rudimentos da leitura e da escrita, sem maiores possibilidades de avanço no processo educativo." (FLACH, 2009, p. 503).

Do ponto de vista da participação política, a CF de 1824 previa eleições indiretas para as nomeações dos Deputados e Senadores para a Assembleia Geral e dos membros dos Conselhos Gerais das Províncias. Elegia-se a massa dos cidadãos ativos em Assembleias Paroquiais os eleitores da Província e os eleitores de províncias, e estes, os representantes da nação e província. Nesta época, o voto era censitário permitindo votar apenas os homens livres que tivessem renda. (BRASIL, CF 1824).

\footnotetext{
${ }^{2}$ Collegios, e Universidades, aonde serão ensinados os elementos das Sciencias, Bellas Letras, e Artes (BRASIL, $\mathrm{CF}, 1824)$.
} 


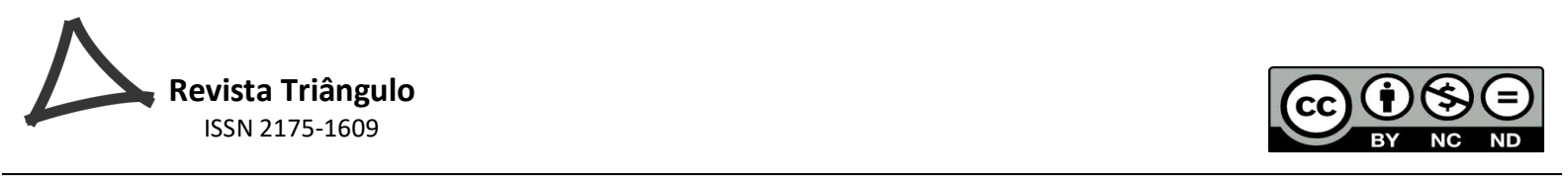

A CF de 1824 vigorou por 65 anos e chega ao fim em 1889 com o marco histórico da Proclamação da República ocorrida em 15 de novembro de 1889. ${ }^{3}$ A Proclamação da República foi impulsionada por uma série de fatores como a crise decorrente do fim da escravidão, conflitos políticos além dos embates com os militares após a Guerra do Paraguai. (SILVA; SOUZA, 2017).

\section{A DECLARAÇÃO DO DIREITO À EDUCAÇÃO NA CONSTITUIÇÃO FEDERAL DE 1891}

Tendo em vista a transição da Monarquia para Estado Nacional Republicano em 1890 institui-se o governo provisório para editar a primeira Constituição Republicana a qual é promulgada em 24 de fevereiro de 1891. A criação da Constituição de 1891 sofre forte influencia liberal norte-americana o que inclusive "[...] deu ao novo Estado que se instaurou no Brasil o nome de "Estados Unidos do Brasil". Tal opção, também foi reforçada tendo em vista que a adoção de um Estado unitário em 1824 não havia "[...] logrado êxito, como era de se esperar em um país de dimensões continentais e em uma época em que os meios de comunicação eram extremamente precários.” (VAINER, 2010, p. 166).

No que tange ao direito à educação, a constituição de 1891 prevê como atribuição do Congresso: a) o desenvolvimento das letras, artes e ciências nos estados (Art. 35, §2 $2^{\circ}$, b) a criação de instituições de ensino superior e secundárias nos estados (Art. 35, $\S 3^{\circ}$ ), e, c) o provimento da instrução secundária no Distrito Federal (Art. 35, § 4 ). A CF de 1891 também passa a prever o ensino leigo nos estabelecimentos públicos (Art. 72, $\S 6^{\circ}$ ). (BRASIL, CF, 1891).

Apesar de a constituição de 1891 ter promovido avanços no que se refere a preocupação com a laicidade do ensino e a criação de instituições para o ensino secundário e de ensino superior, a mesma não faz qualquer menção à instrução primária e sequer menciona a gratuidade e obrigatoriedade do ensino em qualquer etapa, tendo sido completamente “[...] omissa em relação à educação popular, primária.”. (FERRARO, 2008, p. 279).

Aqui dois aspectos merecem atenção. O primeiro é que diferentemente da constituição anterior (1824) a CF de 1891 fundamenta-se nos princípios liberais, e, portanto, não há por

\footnotetext{
${ }^{3}$ O período da primeira república também ficou conhecido como "[...] República Velha, República Oligárquica, República dos Coronéis, República do Café.”(ARANHA, 2006, p. 294).
} 
parte da constituição uma preocupação com os direitos sociais, não cabendo uma preocupação com o caráter público e obrigatório da educação. O segundo, diz respeito à natureza das atribuições ficando a educação à cargo do Congresso o que acaba por evidenciar a compreensão da educação como uma instância política.

Neste período, ocorre a separação entre a Igreja e Estado fortalecendo os ideais do Iluminismo. O Iluminismo fundamentado na ciência e na razão livre e, portanto, não submetido a nenhuma autoridade foi fundamental para os movimentos de resistência à centralidade do poder político monárquico, à instauração da Proclamação da República e à própria criação da CF de 1891.

A CF de 1891 introduz o sistema federativo de estado e extingue o poder moderador instaurando no Brasil um governo representativo, federal e presidencial. No entanto, embora a democracia tenha sido instituída no Brasil legalmente pela CF de 1891 e tenha sido implementada a transição de uma ordem senhorial para uma ordem capitalista, na realidade o Brasil vivia uma oligarquia.

Do ponto de vista dos direitos políticos, a CF de 1891 traz como novidade o voto direto e universal (maioria absoluta de votos), porém, continua excluindo mulheres, analfabetos e mendigos do processo eleitoral ${ }^{4}$ (BRASIL, CF, 1891). Neste sentido, a participação política dos cidadãos na época era pouco representativa. "O primeiro recenseamento no Brasil, em 1872, indicava uma população de quase dez milhões de habitantes, mas, em 1889, eram somente 200.000 os eleitores.” (PORTO, 2012, p.5).

Além disso, o voto não sendo secreto culminou no voto de cabresto ${ }^{5}$ destituindo de sentido a legitimidade dos avanços declarados em instância normativa no cenário político. (FERREIRA, 2009).

As primeiras incursões no sentido da garantia da educação dos negros no Brasil, de acordo com Abreu (2011) surgem no final do século XIX, a partir do desenvolvimento industrial e são implementadas por meio do ensino popular e do ensino profissionalizante. No entendimento da

\footnotetext{
${ }^{4}$ Art 70 - São eleitores os cidadãos maiores de 21 anos que se alistarem na forma da lei. § $1^{\circ}$ - Não podem alistarse eleitores para as eleições federais ou para as dos Estados: $1^{\circ}$ ) os mendigos; $2^{\circ}$ ) os analfabetos; $3^{\circ}$ ) as praças de pré, excetuados os alunos das escolas militares de ensino superior; $4^{\circ}$ ) os religiosos de ordens monásticas, companhias, congregações ou comunidades de qualquer denominação, sujeitas a voto de obediência, regra ou estatuto que importe a renúncia da liberdade Individual. $\S 2^{\circ}$ - São inelegíveis os cidadãos não alistáveis. (BRASIL, CF, 1824 não paginado).

${ }^{5}$ Cada coronel colocava ao lado do eleitor o jagunço como forma de inibir qualquer possibilidade de voto de protesto. (FERREIRA, 2009, p. 230).
} 
autora o investimento no ensino primário tem a ver com o atendimento das demandas políticas do Estado:

O ensino popular é estabelecido mediante a instalação dos grupos escolares urbanos e das escolas isoladas nos bairros. É na República que o ensino primário tem maior ênfase, ou seja, nesse período vai se enfatizar a disseminação da escola primária, a escola do povo. Mas quem era o povo que frequentava a escola? Esse fato tem como pano de fundo um caráter político e autoritário, pois, a escola primária serviria aos republicanos como uma solução ao problema do voto e da representação, além de manter a ordem vigente, isto é, propagar os valores morais e políticos republicanos. (ABREU, 2011, p. 237).

Estes fatores acrescidos às transformações ocorridas no cenário internacional “[...] sobretudo após a Revolução Comunista de 1917, o advento da Constituição Mexicana de 1917 e da Constituição de Weimar de 1919 [...]" impulsionaram o golpe de estado de 1930 liderado por Getúlio Vargas. (VAINER, 2010, p. 171).

Diante da crise econômica proveniente do rompimento das negociações cafeeiras entre os estados de São Paulo e Minas Gerais, após a deposição do presidente Washington Luís, os estados rivais apresentam a candidatura de dois nomes para o cargo de Presidente da República, sendo Júlio Prestes e o oposicionista Getúlio Vargas. O candidato Júlio Prestes ganha as eleições, porém, sob a liderança dos estados de Minas Gerais, Paraíba e Rio Grande do Sul ocorre o golpe de estado de 30 que impede a posse do presidente eleito que é exilado e Getúlio Vargas assume o governo provisório implantando as bases de uma educação nacional. (DALLABRIDA, 2009).

No entendimento de Fernandes (1975) em que pese o fundamento do golpe de 30 tenha tido como base o popularismo, na verdade, tratou-se de um golpe elitista.

Getúlio Vargas popularmente conhecido como o "protetor dos trabalhadores" ou o "pai dos pobres" na verdade "[...] controlava a estrutura sindical, subordinando-a ao Estado. Enquanto manipulava a opinião pública pela propaganda de governo e pela censura, sufocava a oposição com prisões, torturas e exílio." (ARANHA, 2006, p. 295).

No que tange ao campo educacional, no ano de 1931, é aprovada a Reforma Francisco Campos que dentre outras medidas, fixa o curso secundário em dois ciclos, a seriação do currículo e a frequência obrigatória. Embora estas medidas, em especial a obrigatoriedade do ensino em nível secundário, pudessem caracterizar-se como um avanço, na verdade “[...] procuravam produzir estudantes secundaristas autorregulados e produtivos, em sintonia com a 
sociedade disciplinar e capitalista que se consolidava, no Brasil, nos anos de 1930." (DALLABRIDA, 2009, p. 185).

Em contraposição a este contexto, no ano de 1932 a educação pública, obrigatória e gratuita ganha força e significação com o Manifesto dos Pioneiros da Educação Nova. O documento dentre outros argumentos defende a "escola única" com base na "educação comum" para todos. A escola única estaria fundamentada nos princípios da laicidade, gratuidade, obrigatoriedade e coeducação. A escola laica é apresentada como premissa para uma educação sem crenças e disputas religiosas, a gratuidade é apresentada como um princípio igualitário que torna a educação acessível à todos, a obrigatoriedade é apresentada como preceito para a condicionalidade deste ao ensino gratuito e o princípio da co-educação é apresentado como defesa de uma educação em comum e conjunta para pessoas dos dois sexos. (AZEVEDO, 2010).

O manifesto também previa a preocupação com a questão do financiamento da educação, tema marginal e inexistente na CF de 1891, representando um avanço neste sentido, uma vez que até o início da década de 1930 não é possível identificar fatores em torno desta questão. (VIEIRA; VIDAL, 2015).

\section{A DECLARAÇÃO DO DIREITO À EDUCAÇÃO NA CONSTITUIÇÃO FEDERAL DE} 1934

No ano de 1934, é promulgada nova Constituição Federal. No entendimento de Costa (2002, p. 15) “[...] a educação ocupou lugar de destaque na Constituição, vindo a ser tratada no 'Capítulo II' e em outros artigos ao longo do texto legal” incorporando “[...] várias ideias discutidas e propostas por educadores e intelectuais da época."

Do ponto de vista dos direitos políticos, embora a CF de 1934 seja a primeira no ordenamento jurídico brasileiro a declarar o princípio da igualdade entre os sexos e o direito do voto da mulher continua excluindo analfabetos e mendigos do direito ao voto. ${ }^{6}$

\footnotetext{
${ }^{6}$ A partir da CF de 1934 o voto passa a ser obrigatório e secreto para maiores de dezoito anos, no entanto, ainda excluía-se de votar: "a) os que não sabiam ler e escrever; b) as praças-de-pré, salvo os sargentos, do Exército e da Armada e das forças auxiliares do Exército, bem como os alunos das escolas militares de ensino superior e os aspirantes a oficial; c) os mendigos; d) os que estiverem, temporária ou definitivamente, privados dos direitos políticos." (BRASIL, CF, 1934, não paginado).
} 
No campo educacional, a CF de 1934 apresenta a educação como um direito de todos a ser ministrada pela família e pelos poderes públicos e prevê a criação das diretrizes da educação nacional e o ensino primário integral gratuito e de frequência obrigatória extensivo aos adultos. (BRASIL, CF, 1934).

A CF de 1934, ao contrário das constituições anteriores, se constitui como a primeira iniciativa no sentido de garantir o direito à educação gratuita e obrigatória, ainda que restrita ao ensino primário.

Em relação ao ensino posterior ao primário, a CF de 1934 prevê a democratização do acesso e gratuidade do ensino ulterior, no entanto, limita o acesso ao nível secundário a partir da seleção dos estudantes por meio de "[...] provas de inteligência e aproveitamento, ou por processos objetivos apropriados à finalidade do curso." (BRASIL, CF, 1934, não paginado).

A CF de 1934 também é a primeira Constituição a prever financiamento para a educação, (expressos nos artigos 156, parágrafo único e 157, parágrafos $1^{\circ}$ e $2^{\circ}$ ), prevendo não somente os percentuais a serem destinados como também a criação de fundos para a educação. (BRASIL, CF, 1934). As conquistas garantidas pela CF de 1934, porém, permanecem por curto tempo já que em 1937 o país sofre mais um golpe de estado e tem promulgada nova constituição.

O Golpe de 1937 é impulsionado por influencias do contexto internacional. Durante o período após a primeira Guerra Mundial ocorre a militarização da Alemanha, a ascensão de Adolf Hitler ao poder e sua aliança com o regime fascista na Itália e ao regime comunista da então União Soviética. Este contexto internacional evidencia o predomínio de ideologias fascistas e nazistas, as quais ao fundamentar as ações políticas no contexto brasileiro, passam a conferir amplos poderes ao Presidente da República. (VAINER, 2010).

\section{A DECLARAÇÃO DO DIREITO À EDUCAÇÃO NA CONSTITUIÇÃO FEDERAL DE} 1937

No ano de 1937, Getúlio Vargas dá um Golpe de Estado e instala um regime autoritário que fica conhecido como Estado Novo e que dura de 1937 até 1945. "Com a implantação do Estado Novo, Vargas cercou-se de poderes excepcionais. As liberdades civis foram suspensas, o Parlamento dissolvido, os partidos políticos extintos e [...] a repressão policial instalou-se por toda parte.” (PANDOLFI, 1999, p. 10). 
Neste contexto histórico, o perfil político populista de Vargas dá um lugar à um perfil “[...] autoritário, centralizador, avesso à consulta e sobretudo a dividir o poder.” (DINIZ, 1999. p.21)

\begin{abstract}
O Vargas do Estado Novo aparece como um político dominador e voluntarista, dotado de forte ambição de mando, capaz de usar sem vacilar os instrumentos da repressão e da coerção para manter-se no poder, levando tal comportamento às últimas conseqüências, não hesitando mesmo em eliminar de seu caminho os amigos de ontem, os aliados de outrora. (DINIZ, 1999, p. 21- 22).
\end{abstract}

A ditadura estado-novista culminou na imposição de nova Constituição Federal, a qual foi redigida por Francisco Campos e que fica conhecida como constituição "Polaca" por fundamentar-se em preceitos fascistas tal qual a constituição polonesa.

Do ponto de vista dos direitos políticos, a Constituição Federal de 1937 extingue direitos e garantias individuais. Neste período também ocorre a instituição da pena de morte (BRASIL 1937) e a supressão da liberdade de opinião interferindo legalmente nas liberdades, tanto individuais quanto políticas, prevendo inclusive, a censura prévia da imprensa. (PORTO, 2012).

A ditadura do Estado Novo empregava o "[...] uso da repressão a fim de eliminar os opositores ainda existentes, fossem eles de direita ou de esquerda. Muitos foram presos, torturados ou exilados." (SANTOS, 2017, p. 3).

Diante deste cenário, o Brasil vivencia o "[...] agravamento da situação político-social no país onde há um combate das ideias populares, aliadas ao comunismo e ao antifascismo [...]" e é instaurado permanente estado de sítio no país. (FLACH, 2009, p. 505).

No que tange à educação, durante o Golpe de Estado de 1937, a educação fica marcada pela Reforma Capanema implementada por meio de seis decretos publicados entre os anos de 1931 e 1932. (VIEIRA, 2008).

A Reforma Capanema, em consonância com o ordenamento político, implementa a reformulação do ensino primário, secundário, superior e comercial visando atender às demandas do setor produtivo e do desenvolvimento industrial. A reforma institui o ensino secundário organizado em dois ciclos, sendo o primeiro o ginasial e o segundo compreendendo dois cursos (um clássico e outro científico) tendo como ênfase formativa o ensino patriótico.

Com relação à titularidade da oferta da educação, a CF de 1937, em seu artigo 125, prevê que a “[...] educação integral da prole é o primeiro dever e direito natural dos pais. O Estado não será estranho a esse dever, colaborando, de maneira principal ou subsidiária, para facilitar 
a sua execução ou suprir as deficiências e lacunas da educação particular.” (BRASIL, CF, 1937, não paginado).

A partir da CF de 1937 são tidos como preceitos constitucionais a obrigatoriedade e gratuidade do ensino primário, no entanto, a gratuidade prevista estava restrita à limitações constitucionais, logo era necessário alegar escassez de recursos para usufruí-la, caso contrário, o cidadão teria que dar uma "[...] contribuição módica e mensal para a caixa escolar [...]". (BRASIL, 1937, não paginado).

Estando a gratuidade restrita à limitações constitucionais, a educação na CF de 1937 caracteriza-se como um dever da família, cabendo ao Estado apenas “[...] um papel supletivo e subsidiário." (CURY, FERREIRA, 2010, p. 130).

De acordo com ideário explorado por Dallabrida (2014), a cultura escolar do ensino secundário nesta época mantém o dualismo, ofertando ensinos distintos, um destinado às elites e outro à classe trabalhadora, apresentando como fundamento formativo o nacionalismo estadonovista enfatizando as disciplinas de história e geografia do Brasil.

Em suas análises Gomes (2000) explica que neste período, os currículos reforçaram sua perspectiva formativa enciclopédica e literária. Além disso, embora a escola acadêmica fosse primariamente destinada para as elites, o crescimento da renda, a urbanização e outros fatores fez com que a escola acadêmica passasse a ser frequentada pelas classes médias urbanas. No entanto, de acordo com o autor "[...] parte da demanda de vagas na escola secundária era perfeitamente racional, porque o aumento de empregos burocráticos, comerciais e de serviços exigia pessoas com educação geral. Neste sentido a educação acadêmica atuava como educação profissional [...]" (GOMES, 2000, p. 23).

A CF de 1937 embora tivesse mantido o direito da mulher ao voto (Art. 117) ${ }^{7}$, na verdade, significou um retrocesso para o Estado democrático de direito e teve seu fim com o término da Segunda Guerra Mundial e como as demandas por liberdade democrática apresentadas pela sociedade. (VAINER, 2010).

\footnotetext{
${ }^{7}$ Nesta época continuava excluindo os analfabetos, os militares em serviço ativo, os mendigos e os que estivessem privados dos direitos políticos.
} 
Não bastassem os retrocessos trazidos pela CF de 1937, no ano de 1942, é sancionado o Decreto-lei n. 4.244 que organiza o ensino secundário em dois ciclos ${ }^{8}$ e implementa os exames de admissão: ${ }^{9}$ (BRASIL, 1942).

Art. 26. Os trabalhos escolares constarão de lições, exercícios e exames. Os exames serão de três ordens: de admissão, de suficiência e de licença. [...] rt. 34. Os exames de admissão poderão ser realizados em duas épocas, uma em dezembro e outra em fevereiro. $\S 1^{\circ} \mathrm{O}$ candidato a exames de admissão deverá fazer, na inscrição, prova das condições estabelecidas pelo art. 31, e pelas duas primeiras alíneas do art. 32, desta lei. $\S 2^{\circ}$ Poderão inscrever-se aos exames de admissão de segunda época os candidatos que, em primeira época, os não tiverem prestado ou neles não tenham sido aprovados. $\S 3^{\circ} \mathrm{O}$ candidato não aprovado em exames de admissão num estabelecimento de ensino secundário não poderá repeti-lo em outro, na mesma época. (BRASIL, 1942, não paginado).

No entendimento de Oliveira e Araújo (2005, p. 28) o exame de admissão na educação brasileira se constituía como um "verdadeiro "gargalo" já que sendo pouco expressivo o quantitativo daqueles que conseguiam aprovação como consequência diminuía-se o número daqueles que conseguiam dar prosseguimento nos estudos.

\section{A DECLARAÇÃO DO DIREITO À EDUCAÇÃO NA CONSTITUIÇÃO FEDERAL DE} 1946

Com o fim da Segunda Guerra Mundial e com a demanda pelo estabelecimento da redemocratização no Brasil em 1946 convoca-se mais uma Assembleia Constituinte. (VIEIRA, 2007).

A Constituição de 1946 foi realizada durante o governo de Eurico Gaspar Dutra após a deposição de Getúlio Vargas e visava dar fim à repressão institucionalizada instituída pelo Estado Novo. Neste contexto é promulgada nova Constituição Federal prevendo ensino primário obrigatório e gratuito para todos e o ensino oficial subsequente gratuito para àqueles que provassem insuficiência de recursos. (BRASIL, CF, 1946).

\footnotetext{
${ }^{8}$ Art. 2. ${ }^{\circ} \mathrm{O}$ ensino secundário será ministrado em dois ciclos. O primeiro compreenderá um só curso: o curso ginasial. O segundo compreenderá dois cursos paralelos: o curso clássico e o curso científico. Art. $3^{\circ} \mathrm{O}$ curso ginasial, que terá a duração de quatro anos, destinar-se-á a dar aos adolescentes os elementos fundamentais do ensino secundário. Art. $4^{\circ}$. O curso clássico e o curso científico, cada qual com a duração de três anos, terão por objetivo consolidar a educação ministrada no curso ginasial e bem assim desenvolvê-la e aprofundá-la. No curso clássico, concorrerá para a formação intelectual, além de um maior conhecimento de filosofia, um acentuado estudo das letras antigas; no curso científico, essa formação será marcada por um estudo maior de ciências. (BRASIL, 1942).

${ }^{9}$ Os exames de admissão foram extintos somente no ano de 1971 por meio da Lei 5.692.
} 
No entendimento de Cury e Ferreira (2010, p. 130) a CF de 1946 "[...] proporcionou um novo alento à educação, posto que, na sua essência, não se diferencia da Constituição de 1934, repondo e assimilando os avanços por ela introduzidos, inclusive no que diz respeito à adoção do princípio do ensino primário obrigatório [...]”.

Do ponto de vista dos direitos políticos, a CF de 1946 restabelece direitos fundamentais, prevendo o direito de greve e a liberdade de associação e extinguido a censura e a pena de morte. Além disso, a CF de 1946 declara que todos são iguais perante à lei estabelecendo pela primeira vez o sufrágio universal e secreto. (BRASIL, CF, 1946).

No ano de 1948 inicia-se no Congresso Nacional o primeiro projeto da Lei de Diretrizes e Bases da Educação Nacional, no entanto este é arquivado. O projeto é retomado no Legislativo Federal dez anos depois por meio do substitutivo Lacerda o qual saía em defesa da escola privada. Tal perspectiva entrou em divergência com os pressupostos defendidos pelo Manifesto dos Pioneiros da Educação em especial o pressuposto do fortalecimento da escola pública.

Em 20 de dezembro de 1961, é promulgada a primeira Lei de Diretrizes e Bases da Educação Nacional (LDBEN 4.024/1961) que passa a prever em seu artigo 27 o ensino primário obrigatório com duração mínima de quatro anos a partir dos sete anos e prevendo a formação de classes especiais ou cursos supletivos para àqueles que não tiveram acesso à escolarização na idade própria. (BRASIL, LDBEN, 1961, não paginado).

No entanto, tal obrigatoriedade não necessariamente previa a titularidade do Estado na oferta da educação, já que a lei estabelecia a educação no lar. Além disso, isentava o Estado de ofertar matrícula no caso de comprovado estado de pobreza, insuficiência de escolas, matrícula encerrada ou doença ou anomalia grave, o que pode ser constado no art. 30, parágrafo único da referida lei:

Art. 30. Não poderá exercer função pública, nem ocupar emprego em sociedade de economia mista ou empresa concessionária de serviço público o pai de família ou responsável por criança em idade escolar sem fazer prova de matrícula desta, em estabelecimento de ensino, ou de que lhe está sendo ministrada educação no lar. Parágrafo único. Constituem casos de isenção, além de outros previstos em lei: a) comprovado estado de pobreza do pai ou responsável; b) insuficiência de escolas; c) matrícula encerrada; d) doença ou anomalia grave da criança. (BRASIL, LDEN, 1961, não paginado, grifo nosso).

No entendimento de Cury (2008, p. 1192 - 1193), a LDBEN 4.024/1961 aprofunda a desigualdade social já que evidencia claramente quem "não precisa" ser destinatário da 
educação obrigatória e em poucas exceções “[...] a face da desigualdade social foi tão clara: o indivíduo em estado de pobreza está privado das virtudes de um direito proclamado como essencial para a vida social."

A referida LDB prevê um capítulo exclusivo para o Ensino Médio e em seu artigo 34 estabelece a organização deste "[...] em dois ciclos, o ginasial e o colegial [...]", abrangendo, entre outros, “[...] os cursos secundários, técnicos e de formação de professores para o ensino primário e pré-primário.” (BRASIL, LDBEN, 1961, não paginado).

No entendimento de Gomes (2000) a reforma de 1961, embora tenha descentralizado os currículos do Ensino Médio, não promoveu alterações na estrutura desta etapa de ensino, o que fez com que os privilégios continuassem mantidos.

No ano de 1964 instaura-se no país o golpe civil-militar, o qual ocorre por meio da aliança estabelecida entre os empresários e os militares. (SAVIANI, 2008).

O golpe de 1964 encerra o governo de João Goulart significando muitos retrocessos contra a democracia fazendo desaparecer o Estado de direito que lentamente buscava sua consolidação já que o mesmo tem como fundamento a governabilidade ditatorial com base em atos violentos, repressão e censura. Em nome da segurança nacional justificou-se " "[...] todo o tipo de repressão, desde cassação de direitos políticos, censura da mídia, até prisão, tortura, exílio e assassinato.” (ARANHA, 2006, p. 296).

\section{A DECLARAÇÃO DO DIREITO À EDUCAÇÃO NA CONSTITUIÇÃO FEDERAL DE 1967}

Em 1964 ocorre a ditadura civil-militar ${ }^{10}$ e dois anos depois ocorre a promulgação da Constituição de 1967, a qual foi modificada por sucessivos atos institucionais.

No que se refere à organização do ensino, a partir constituição de 1967, passa-se a prever a obrigatoriedade do ensino não mais por etapa e sim por faixa etária, compreendendo a obrigatoriedade do ensino dos 7 aos 14 anos. A gratuidade do ensino estava restrita ao ensino primário, ficando o ensino secundário e superior condicionado ao aproveitamento de estudos e à prova de insuficiência de recursos. A CF de 1967 inclusive transfere a responsabilidade pelo custeio da educação ao titular do direito, prevendo que sempre que possível ocorra a

${ }^{10}(1964-1985)$ 
substituição do regime de gratuidade pela concessão de bolsas de estudo sendo "[...] exigido o posterior reembolso no caso de ensino de grau superior [...]” (BRASIL, CF, 1967, não paginado).

Além disso, a CF de 1967 denota o papel secundarizado do Estado na oferta obrigatória e gratuita do ensino, tanto ao prever a educação no lar quanto ao prever que o ensino é livre à iniciativa particular, conforme é possível constatar em seu art. 168:

\begin{abstract}
A educação é direito de todos e será dada no lar e na escola; assegurada a igualdade de oportunidade, deve inspirar-se no princípio da unidade nacional e nos ideais de liberdade e de solidariedade humana. $\S 1^{\circ}$ - O ensino será ministrado nos diferentes graus pelos Poderes Públicos. $\S 2^{\circ}$ - Respeitadas as disposições legais, o ensino é livre à Iniciativa particular, a qual merecerá o amparo técnico e financeiro dos Poderes Públicos, inclusive bolsas de estudo. [...] (BRASIL, CF, 1967, não paginado, grifo nosso).
\end{abstract}

No entendimento de Vieira e Vidal (2015, p. 24) a CF de 1967 retrata o descompromisso do Poder Público com a educação pública. Tal Constituição:

[...] guarda fortes semelhanças com o texto de 1937, afastando-se do teor democrático das constituições de 1934 e de 1946. É flagrante o apoio ao setor privado, [...] ou seja, mantém-se o espírito da LDB de 1961. Por outro lado, em lugar da vinculação de recursos para as diferentes esferas do poder público, o que se vê é uma passagem que retrata o descompromisso destas para com a educação pública.

No entendimento de Fávero (2001, p. 253) todos os esforços voltados para o campo da educação neste período restringiram-se a "[...] adequar o projeto educacional, em todos os níveis e em todas as modalidades do ensino e da formação profissional, ao novo projeto nacional. Para tanto, princípios, diretrizes, experiências, mecanismos e instrumentos foram abandonados, extintos ou substituídos."

No que se refere ao financiamento, portanto, tendo como perspectiva a redução da responsabilidade com a oferta do ensino público, a constituição de 1967 “[...] baixada pelo regime militar, eliminou a vinculação orçamentária constante das Constituições de 1934 e de 1946, que obrigava a União, os estados e os municípios a destinar um percentual mínimo de recursos para a educação.” (SAVIANI, 2008, p. 298).

No ano de 1968 por meio da lei 5.537, cria-se o Fundo Nacional de Desenvolvimento (FNDE), no entanto, tal fundo não tinha como finalidade o atendimento da educação pública, 
pelo contrário, a ideia era repassar fundos públicos para o ensino privado para que este, como contrapartida, garantisse reserva de vagas para bolsa de estudos para alunos carentes:

Sua finalidade era reunir recursos financeiros governamentais de diversas fontes e canalizá-los para o financiamento de projetos de ensino, inclusive alimentação escolar e bolsas de estudo para alunos carentes na rede privada. Os projetos seriam apresentados pelo governo federal e pelos governos estaduais e municipais, bem como por estabelecimentos privados. As escolas dariam uma compensação pelo financiamento recebido, mediante a reserva de vagas para bolsas de estudo, bolsas de manutenção ou de estágio, distribuídas pelo próprio FNDE. Em suma, fundos públicos, criados por decisão estatal para financiarem a expansão das redes públicas, acabaram sendo estratégicos para a manutenção e a expansão do setor privado. (CUNHA, 2014, p. 365).

Com relação aos direitos políticos embora a CF de 1967 mantenha o voto com um direito de homens e mulheres ${ }^{11}$ e embora avance ao declarar em seu artigo 150 que todos "[...] são iguais perante a lei, sem distinção, de sexo, raça, trabalho, credo religioso e convicções políticas" prevendo inclusive punição para o preconceito de raça, na verdade fica longe de se materializar no campo da prática, já que contraditoriamente advoga em favor da democracia e ao mesmo tempo implementa um regime autoritário e opressor. (BRASIL, CF, 1967, não paginado).

No ano de 1968 o governo sofre um golpe dentro do próprio governo e é implementado o Ato Institucional n.5, tornando a ditadura-civil-militar ainda mais violenta, introduzindo "[...] profundas mudanças em relação ao poder e aos direitos individuais.” (GROFF, 2008, p.122).

No ano de 1969 é aprovada a Emenda Constitucional 1/1969² (BRASIL, EC 1, 1969) que confere plenos poderes ao regime ditatorial. A EC 1/1069:

[...] ampliou a centralização do poder e o autoritarismo. Ela incorporou ao seu texto medidas autoritárias dos Atos Institucionais; consagrou a intervenção federal nos Estados; cassou a autonomia administrativa das capitais e outros municípios; impôs restrições ao Poder Legislativo; validou o regime dos decretos-leis; manteve e ampliou as estipulações restritivas da Constituição de 1967, quer em matéria de garantias individuais, quer em matéria de direitos sociais. (GROFF, 2008, p.122).

\footnotetext{
${ }^{11}$ Excluindo-se ainda: os analfabetos; os que não sabiam exprimir-se na língua nacional e os que estivessem privados, temporária ou definitivamente, dos direitos políticos. (BRASIL, CF, 1967, não paginado).

${ }^{12}$ A EC 1/1969 fica conhecida informalmente como a "Constituição de 1969" e materializa documentalmente as mudanças promovidos pelo golpe do regime civil-militar.
} 
Com relação à educação, a EC 1/1969 mantém a redação da CF de 1967, porém, deixando de incumbir o Poder Público de conceder bolsas de estudo para os anos ulteriores ao ensino primário, o que denota ainda mais retrocessos.

Em 11 de agosto de 1971, ainda em meio ao cenário de ditadura civil-militar é promulgada a lei $5.692^{13}$ a qual busca materializar os pressupostos formativos advindos do acordo entre o Brasil e os Estados Unidos (MEC-USAID) implementando compulsoriamente o ensino técnico:

Essa lei estabeleceu uma educação tecnologicamente orientada que começou a profissionalizar a criança na $7^{\mathrm{a}}$ série, sendo a escola secundária completamente profissionalizante. Esta foi uma maneira de profissionalizar mão-de-obra barata para as companhias multinacionais que adquiriram grande poder econômico no País sob o regime da ditadura militar [...] (BARBOSA, 1989, p. 170).

Neste contexto de repressão e barbárie, foram retiradas do currículo escolar as disciplinas que potencialmente pudessem desenvolver o pensamento e a criticidade como a filosofia e a história. A arte embora tenha permanecido, só se manteve a partir de sua perspectiva técnica e instrumental para atender as demandas do trabalho industrial. (BARBOSA, 1989).

A educação técnica compulsória esteve à serviço dos fins formativos do Regime Militar, e, em que pese apresentar o preceito normativo da ampliação do ensino obrigatório, de acordo com Flach $(2009$, p. 507) este tornou-se “[...] letra morta, pois não existiam recursos materiais e humanos para atender à demanda existente."

A Reforma de 1971 sofreu forte resistência por parte da sociedade e dos educadores e não se materializou em vários pontos, em especial, no que concerne ao ensino técnico obrigatório não chegando a cobrir sequer $20 \%$ da população que deveria frequentar o Ensino Médio. (GOMES, 2000, p. 34)

No final da década de 1970 e início da década de 1980 foram crescendo os movimentos em torno de uma educação pública, obrigatória e gratuita e aos poucos foi se "[...] constituindo uma nova política educacional, contrária àquela que ocorreu nos governos militares [...]" (FLACH, 2009, p. 508).

$\mathrm{Na}$ década de 1980 ocorre um aumento de matrículas de estudantes no Ensino Médio, no entanto, a expansão da escolaridade nesta etapa de ensino ocorre predominantemente no ensino

\footnotetext{
${ }^{13}$ Por se apresentar como lei que "Fixa Diretrizes e Bases para o ensino de $1^{\circ} \mathrm{e} 2^{\circ}$ graus, e dá outras providências" não há um consenso pelos autores da bibliografia especializada de que esta lei se trate de uma LDB pois a mesma exclui o Ensino Superior.
} 
noturno e as camadas populares foram inseridas "[...] numa escolarização amplamente desigual.” (GOMES, 2000, p. 40).

\title{
A DECLARAÇÃO DO DIREITO À EDUCAÇÃO NA CONSTITUIÇÃO FEDERAL DE 1988
}

A ditatura civil-militar perdurou por 21 anos e findou no ano de 1985 tendo em vista a busca pela redemocratização do país por parte da população brasileira. A nova constituição é promulgada em 5 de outubro de 1988 e fica conhecida como Constituição Cidadã, por ser resultado das reinvindicações dos diversos segmentos da sociedade. Além de seu caráter democrático, a CF de 1988 significou um avanço na retomada e fortalecimento do Estado Democrático de Direito, manifestando sanções contra toda e qualquer transgressão de direitos:

\begin{abstract}
Após vinte anos de ditadura e violação aos direitos humanos, a Carta Política de 1988 consagrou em especial os direitos individuais, dando atenção especial ao princípio da dignidade da pessoa humana (art. $1^{\circ}$, III) e aos direitos conexos a este princípio, como a proibição da tortura $\left(5^{\circ}, \mathrm{III}\right)$ e a prática de racismo como crime inafiançável $\left(5^{\circ}\right.$, XLII), entre outros. (VAINER, 2010, p. 188, grifo nosso).
\end{abstract}

A CF de 1988 prevê em seu artigo 5 que "homens e mulheres são iguais em direitos e obrigações" e o voto secreto e direto é obrigatório à todos àqueles maiores de 18 anos de idade, ficando facultado aos analfabetos, aos maiores de setenta anos e aos maiores de dezesseis anos e menores de dezoito anos. (BRASIL, CF, 1988, não paginado).

Do ponto de vista educacional, a CF 1988 representa um avanço no que tange ao direito à educação, qualificando pela primeira vez a educação obrigatória como direito público subjetivo:

Direito público subjetivo é aquele pelo qual o titular de um direito pode exigir direta e imediatamente do Estado o cumprimento de um dever e de uma obrigação. O titular deste direito é qualquer pessoa, de qualquer idade, que não tenha tido acesso à escolaridade obrigatória na idade apropriada ou não. É válida sua aplicação para os que, mesmo tendo tido acesso, não puderam completar o ensino [...] Trata-se de um direito subjetivo, ou seja, um sujeito é o titular de uma prerrogativa própria deste indivíduo, essencial para a sua personalidade e para a cidadania. E se chama direito público, pois, no caso, trata-se de uma regra jurídica que regula a competência, as obrigações e os interesses fundamentais dos poderes públicos, explicitando a extensão do gozo que os cidadãos possuem quanto aos serviços públicos. O sujeito desse dever 
é o Estado sob cuja alçada estiver situada essa etapa da escolaridade. (CURY, 2000, p. 21).

O direito público subjetivo, conforme o ideário explorado por Cury (2000, p. 21-22) “[...] explicita claramente a vinculação substantiva e jurídica entre o objetivo (dever do Estado) e o subjetivo (direito da pessoa)."

De acordo com Gehlen (2015) houve um avanço na doutrina jurídica, uma vez que antes da CF de 1988 a normas relativas aos direitos sociais eram concebidas como normas pragmáticas e, portanto, não autoaplicáveis. Depois da redemocratização do país e da CF de 1988, os direitos sociais, dentre os quais a educação, passaram a constituir-se como direitos fundamentais autoaplicáveis, ou seja, os direitos sociais passaram a ser declarados como direitos a serem efetivados em grau máximo e para todos.

A educação, nesta perspectiva, “[...] configura-se como um instrumento jurídico de controle da atuação do poder estatal, pois permite ao seu titular constranger judicialmente o Estado a executar o que deve." (DUARTE, 2004, p. 113).

Os direitos e deveres em educação instituídos a partir da obrigatoriedade, portanto, caracterizam-se como “[...] um modo de sobrepor uma função social relevante e imprescindível de uma democracia a um direito civil." (CURY, 2002a, p. 249).

Além disso, em um país em que o direito à educação se consolida a partir das desigualdades, a educação compulsória consiste em um "[...] instrumento para que a educação deixe de ser um privilégio de classes ou grupos sociais e passe a ser garantida como direito fundamental para todos." (PINTO; ALVES, 2010, não paginado).

Os preceitos da CF 1988 vão orientar a redação do Estatuto da Criança e do Adolescente (ECA) sob a lei 8.069, o qual prevê em seu capítulo IV $^{14}$ o direito à educação visando o desenvolvimento pleno, o preparo para o exercício da cidadania e a qualificação para o trabalho, prevendo em seu artigo 54, o dever do Estado de assegurar à criança e ao adolescente:

I - ensino fundamental, obrigatório e gratuito, inclusive para os que a ele não tiveram acesso na idade própria; II - progressiva extensão da obrigatoriedade e gratuidade ao ensino médio; III - atendimento educacional especializado aos portadores de deficiência, preferencialmente na rede regular de ensino; IV - atendimento em creche e pré-escola às crianças de zero a cinco anos de idade; $\mathrm{V}$ - acesso aos níveis mais elevados do ensino, da pesquisa e da criação artística, segundo a capacidade de cada um; VI - oferta de ensino noturno regular, adequado às condições do adolescente

14 “Do Direito à educação, à cultura, ao esporte e ao lazer" 
trabalhador; VII - atendimento no ensino fundamental, através de programas suplementares de material didático-escolar, transporte, alimentação e assistência à saúde. (BRASIL, ECA, 1990, não paginado).

O ECA atribui legalmente aos pais e/ou familiares ${ }^{15}$ a obrigação de matricular o filho e acompanhar sua frequência e aproveitamento escolar e atribui ao Ministério Público ${ }^{16}$ a obrigação de "[...] zelar pelo efetivo respeito aos direitos e garantias legais assegurados às crianças e adolescentes, promovendo as medidas judiciais e extrajudiciais cabíveis.” (BRASIL, ECA, 1990, não paginado).

Três meses antes da promulgação da LDBEN de 1996, em 12 de setembro do mesmo ano, é aprovada a Emenda Constitucional 14/1996 a qual dentre outros preceitos ${ }^{17}$ dá nova redação aos incisos I e II do artigo 208 da Constituição Federal, indicando que o dever do Estado com a educação deverá ser efetivado garantindo: "I - ensino fundamental obrigatório e gratuito, assegurada, inclusive, sua oferta gratuita para todos os que a ele não tiveram acesso na idade própria [e] II - progressiva universalização do ensino médio gratuito [...]” (BRASIL, EC 14, 1996).

A partir da EC 14/1996, a progressiva extensão da obrigatoriedade e gratuidade do Ensino Médio, prevista pela CF de 1988, é substituída pela progressiva universalização, destituindo de caráter obrigatório e gratuito esta etapa de ensino.

Embora a perspectiva da universalização em alguma medida pudesse representar um avanço ao indicar a responsabilização do Estado diante da garantia do direito à educação em nível médio, tal perspectiva é desconstruída dentro da própria EC 14/1996 que ao prever uma alteração no artigo art. 60 do Ato das Disposições Constitucionais Transitórias (ADCT), passa a adotar a seguinte redação:

Nos dez primeiros anos da promulgação desta emenda, os Estados, o Distrito Federal e os Municípios destinarão não menos de sessenta por cento dos recursos a que se refere o caput do art. 212 da Constituição Federal, a manutenção e ao desenvolvimento do ensino fundamental, com o objetivo de assegurar a universalização de seu atendimento e a remuneração condigna do magistério. (BRASIL, EC 14, 1996, não paginado, grifo nosso).

\footnotetext{
${ }^{15}$ Artigo 129

${ }^{16}$ Art. 201, inciso VII

${ }^{17}$ Modifica os arts. 34, 211 e 212 da Constituição Federal e dá nova redação ao art. 60 do Ato das Disposições constitucionais Transitórias.
} 


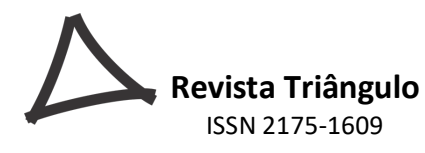

O preceito constitucional da EC 14/96, reitera uma perspectiva que marcou historicamente a educação brasileira que é a centralidade do atendimento apenas ao Ensino Fundamental. É por meio desta EC, inclusive, que se estabelece no ano subsequente a criação do Fundo de Manutenção e Desenvolvimento do Ensino Fundamental e de Valorização do Magistério (FUNDEF) ${ }^{18}$ o qual destinará recursos financeiros exclusivamente para o Ensino Fundamental.

De acordo com Alves e Araújo (2013) a centralidade no Ensino Fundamental não foi aleatória ou inconsciente, mas sim uma deliberação articulada com um projeto de governo orientado a partir das determinações do Banco Mundial e demais organismos multilaterais.

No ano de 1996 é promulgada a LDBEN 9.394. (BRASIL, LDBEN, 1996). O contexto de formulação da LDBEN compreendeu o período de 1986 a 1996, tendo sido marcado por disputas e contradições, já que se tratava de um contexto pós ditadura civil-militar em que a sociedade se mobilizava pela busca da redemocratização do país.

Neste contexto, os projetos de formação em disputa apresentavam diferentes concepções, uma advinda das forças sociais progressistas, populares e democráticas da sociedade civil e em defesa de uma educação pública, gratuita, universal e de qualidade para todos, e outra, advinda das forças liberais conservadoras e em defesa de um projeto educacional neoliberal visando o atendimento das demandas capitalistas. (BOLLMANN, AGUIAR, 2016).

O embate em torno do projeto de educação da LDBEN 9.394/1996 ocorre entre a sociedade e a própria instância governamental (Projeto Darcy Ribeiro ${ }^{19}$ ). Neste sentido, após muitos embates, em uma sessão rápida com duração de aproximadamente 2 horas o governo aprova o seu próprio projeto "[...] contrariando e desprezando todo o trabalho de elaboração coletiva, historicamente realizado pela sociedade brasileira [...]” (BOLLMANN, AGUIAR, 2016, p. 418).

Apesar deste contexto contraditório, alguns avanços importantes foram conquistados. Como fator positivo e resultado dos tensionamentos em torno da LDBEN 9.394/1996, importa observar a conquista da luta de entidades, movimentos e educadores para garantir os conceitos de democratização da educação, dentre eles, o conceito de Educação Básica. A Educação

\footnotetext{
${ }^{18}$ Regulamentado pela lei 9.424/1996.

19 "O projeto de uma nova LDB foi apresentado pelo deputado Octávio Elísio em dezembro de 1988, dois meses depois de promulgada a Constituição, incorporando as principais reivindicações dos educadores progressistas, inclusive referentes ao ensino médio. O longo debate em torno do Projeto Original e do Substitutivo Jorge Hage foi atravessado pela apresentação de um novo projeto pelo Senador Darcy Ribeiro e este foi o texto aprovado em 20 de dezembro de 1996, como Lei n. 9.394.” (FRIGOTTO, CIAVATTA, RAMOS, 2005, p. 10).
} 
Básica constituída pela Educação Infantil, pelo Ensino Fundamental e pelo Ensino Médio, compreendida como uma educação de base para todos, provoca um alargamento na concepção de educação. (CURY, 2002, 2008).

No entendimento de Cury (2002) o conceito de Educação Básica enquanto educação de base, possibilita a disseminação de uma nova consciência, uma nova significação, como “[...] um conceito mais do que inovador para um país que, por séculos, negou, de modo elitista e seletivo, a seus cidadãos o direito ao conhecimento pela ação sistemática da organização escolar." (CURY, 2002, p. 170).

Para o autor, a Educação Básica avança como conceito e como direito:

Como conceito novo, ela traduz uma nova realidade nascida de um possível histórico que se realizou e de uma postura transgressora de situações preexistentes, carregadas de caráter não democrático. Como direito, ela significa um recorte universalista próprio de uma cidadania ampliada e ansiosa por encontros e reencontros com uma democracia civil, social, política e cultural. (CURY, 2008, p. 294).

A educação, a partir da noção de Educação Básica, portanto, passa a ser concebida como um mecanismo e/ou instrumento para a redução das desigualdades. (CURY, 2002a, 2008). Estar na escola, é o primeiro passo para a efetivação do direito à educação.

Além da força que imprime na declaração do direito à educação, o conceito de Educação Básica avança ao conferir uma identidade ao Ensino Médio já que, ao prever a formação comum e para todos, rompe com a histórica polarização entre formação profissional técnica e formação propedêutica visando a continuidade no Ensino Superior. (SILVA, 2015).

No ano de 1996, conforme já evidenciado neste estudo em decorrência da EC 14/96, é criado o Fundo de Manutenção e Desenvolvimento do Ensino Fundamental e de Valorização do Magistério (FUNDEF) por meio da lei n. 9.424/1996. O referido fundo passa a prever a distribuição de recursos financeiros para o Ensino Fundamental.

A lei 9.424/1996, além de estabelecer a criação do fundo, também prevê preceitos legais em torno do padrão de qualidade do ensino, estabelecendo em seu art. $13^{\circ}$ :

I - estabelecimento do número mínimo e máximo de alunos em sala de aula; II capacitação permanente dos profissionais de educação; III - jornada de trabalho que incorpore os momentos diferenciados das atividades docentes; IV - complexidade de funcionamento; V - localização e atendimento da clientela; VI - busca do aumento do padrão de qualidade do ensino. (BRASIL, Lei 9.424, 1996, não paginado). 
Ainda que restringindo seu campo de atuação ao Ensino Fundamental, essa lei representa um avanço, tanto na garantia do direito à educação por meio da criação do fundo, quanto pela valorização da carreira docente ao prever direitos até então não assegurados pela legislação educacional como o número máximo de alunos em sala de aula e a jornada de trabalho prevendo momentos diferenciados para o exercício das atividades docentes para além das atividades de ensino em sala de aula.

No ano de 2005 é aprovada a lei 11.114/2005 que altera a LDBEN 9.394/1996 para tornar obrigatório o início do Ensino Fundamental aos seis anos de idade. A lei apresenta problemas em sua efetivação, já que não é suficiente apenas prever a entrada das crianças mais cedo mas pensar toda uma proposta formativa de um Ensino Fundamental ampliado, o que não ocorreu. (UNDIME, 2005).

No ano subsequente, o quadro permanece inalterado, e mesmo após as inúmeras críticas, especialmente quanto à falta de amplas discussões em torno dos processos formativos, tempos e espaços escolares para qualificar a entrada das crianças mais cedo no Ensino Fundamental, aprova-se a lei 11.274/2006 que amplia para 9 anos o tempo de duração desta etapa de ensino e torna obrigatória a matrícula das crianças já aos seis anos de idade, ou seja, uma lei que continua atuando na mesma direção da lei anterior e se deparando com os mesmos desafios para sua implementação. (BRASIL, LEI 11.274, 2006).

Também no ano de 2006, dez anos após a exaração da LDBEN 9394/1996 é aprovada a criação do Fundo de Manutenção e Desenvolvimento da Educação Básica e Valorização dos Profissionais da Educação (FUNDEB) ${ }^{20}$ regulamentado pela lei 11.494/2007.

Treze anos após a promulgação da LDBEN 9.394/1996, é aprovada a Emenda Constitucional 59/2009, a qual dentre outros $\operatorname{preceitos}^{21}$ inclui a obrigatoriedade e gratuidade da educação dos 4 aos 17 anos e a ampliação do atendimento dos programas suplementares para toda a Educação Básica (BRASIL, EC 59, 2009) avançando no sentido da garantia do direito à

\footnotetext{
${ }^{20}$ A Portaria 1.055, de 25 de abril de 2017 redefine as regras de adesão do programa. (BRASIL, 2017).

${ }^{21}$ São preceitos da EC 59/2009: a) A obrigatoriedade e gratuidade do ensino dos 4 aos 17 anos inclusive para aqueles que não tiveram acesso na idade própria; b) A ampliação da abrangência do atendimento dos programas suplementares para toda a Educação Básica;c) A colaboração entre os entes federados para garantir o ensino obrigatório; d) A universalização, garantia de padrão de qualidade e equidade do ensino obrigatório; e) A inclusão do Plano Nacional de Educação (PNE) na Constituição Federal (CF) e a partir deste a criação do Sistema Nacional de Educação (SNE); f) A vinculação de um percentual do PIB para aplicar em Educação; e, g) A extinção gradual da Desvinculação das Receitas da União (DRU). (BRASIL, EC 59, 2009).
} 
educação e representando o maior tempo de educação formal obrigatória e gratuita vivida pelo país:

Quadro 1 - O direito à educação no ordenamento jurídico brasileiro

\begin{tabular}{|c|c|c|c|c|}
\hline Legislação & $\begin{array}{c}\text { Período } \\
\text { Histórico }\end{array}$ & Duração & Declaração do direito à Educação & $\begin{array}{l}\text { Tempo de } \\
\text { educação }\end{array}$ \\
\hline CF 1824 & Império & $\begin{array}{c}1824-1889 \\
65 \text { anos }\end{array}$ & $\begin{array}{l}\text { Prevê a instrução primária e gratuita a } \\
\text { todos os cidadãos, porém, os escravos } \\
\text { não eram considerados cidadãos }\end{array}$ & $\begin{array}{c}\text { Não } \\
\text { especifica }\end{array}$ \\
\hline CF 1891 & República & $\begin{array}{c}1891-1930 \\
40 \text { anos }\end{array}$ & $\begin{array}{c}\text { Não faz menção à instrução primária e } \\
\text { sequer menciona a gratuidade e } \\
\text { obrigatoriedade }\end{array}$ & $\begin{array}{c}\text { Não } \\
\text { especifica }\end{array}$ \\
\hline CF 1934 & $\begin{array}{l}\text { Golpe de Estado } \\
\text { de } 1930\end{array}$ & $\begin{array}{c}1934-1937 \\
3 \text { anos }\end{array}$ & $\begin{array}{c}\text { Prevê o ensino primário integral gratuito e } \\
\text { de frequência obrigatória extensivo aos } \\
\text { adultos }\end{array}$ & 4 anos \\
\hline CF 1937 & $\begin{array}{c}\text { Golpe de Estado } \\
\text { de } 1937\end{array}$ & $\begin{array}{c}1937-1945 \\
8 \text { anos }\end{array}$ & $\begin{array}{l}\text { Prevê a obrigatoriedade e a gratuidade do } \\
\text { ensino primário e prevê a titularidade dos } \\
\text { pais na garantia do direito à educação } \\
\text { Prevê que o Estado ocupe papel } \\
\text { subsidiário na garantia do direito à } \\
\text { educação já que a gratuidade prevista } \\
\text { estava restrita à limitações constitucionais } \\
\text { sendo necessário alegar escassez de } \\
\text { recursos para usufruí-la }\end{array}$ & 4 anos \\
\hline CF 1946 & Redemocratização & $\begin{array}{c}1946-1967 \\
21 \text { anos }\end{array}$ & Prevê ensino primário a partir dos 7 anos & 4 anos \\
\hline $\begin{array}{c}\text { LDBEN } \\
4.024 / 1961\end{array}$ & $\begin{array}{l}\text { Redemocratização } \\
\text { / } \\
\text { Ditadura civil- } \\
\text { militar de } 1964\end{array}$ & $\begin{array}{c}1961-1971 \\
10 \text { anos }\end{array}$ & $\begin{array}{c}\text { Prevê ensino primário a partir dos } 7 \text { anos } \\
\text { Não prevê a titularidade do Estado na } \\
\text { oferta da Educação prevendo a educação } \\
\text { no lar e isenta o Estado da } \\
\text { responsabilidade de garantir o direito à } \\
\text { educação no caso de insuficiência de } \\
\text { escolas e/ou de matriculas encerradas. } \\
\text { Excetuava aos pais a responsabilidade de } \\
\text { cumprir com a obrigatoriedade da } \\
\text { matrícula dos filhos no caso de pobreza } \\
\text { extrema e/ou de doenças ou anomalias } \\
\text { graves. }\end{array}$ & 4 anos \\
\hline CF 1967 & $\begin{array}{l}\text { Ditadura civil- } \\
\text { militar de } 1964\end{array}$ & $\begin{array}{c}1967-1969 \\
2 \text { anos }\end{array}$ & $\begin{array}{c}\text { Prevê o ensino fundamental dos } 7 \text { aos } 14 \\
\text { anos } \\
\text { Implementa o ensino técnico } \\
\text { profissionalizante } \\
\text { Denota o papel secundarizado do Estado } \\
\text { na oferta obrigatória e gratuita do ensino, } \\
\text { tanto ao prever a educação no lar quanto } \\
\text { ao prever que o ensino é livre à iniciativa } \\
\text { particular. }\end{array}$ & 8 anos \\
\hline $\begin{array}{c}\text { Lei } \\
5.692 / 1971\end{array}$ & $\begin{array}{l}\text { Ditadura civil- } \\
\text { militar de } 1964\end{array}$ & $\begin{array}{l}1971-1996 \\
25 \text { anos }\end{array}$ & $\begin{array}{c}\text { Prevê o direito à educação dos } 7 \text { aos } 14 \\
\text { anos a partir do corte etário }\end{array}$ & 8 anos \\
\hline
\end{tabular}




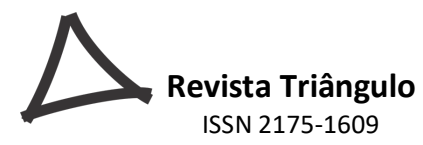

ISSN 2175-1609

\begin{tabular}{|c|c|c|c|c|}
\hline EC 1/1969 & AI-5 & $\begin{array}{c}1969-1987 \\
18 \text { anos }\end{array}$ & $\begin{array}{l}\text { Reitera o corte etário dos } 7 \text { aos } 14 \text { anos } \\
\text { conforme previsto pelas normatizações } \\
\text { anteriores }\end{array}$ & 8 anos \\
\hline CF 1988 & Redemocratização & $\begin{array}{l}1988-\overline{-} \\
32 \text { anos até } \\
\text { o presente } \\
\text { momento }\end{array}$ & $\begin{array}{l}\text { Prevê o ensino fundamental a partir dos } 7 \\
\qquad \text { anos } \\
\text { Apresenta a educação como direito-dever e } \\
\text { declara a educação como direito público } \\
\text { subjetivo } \\
\text { Prevê a titularidade do Estado na oferta e a } \\
\text { titularidade dos pais na matrícula dos } \\
\text { filhos }\end{array}$ & 8 anos \\
\hline $\begin{array}{l}\text { Lei } \\
8.069 / 1990 \\
(\text { ECA })\end{array}$ & Redemocratização & $\begin{array}{l}1990- \\
30 \text { anos até } \\
\text { o presente } \\
\text { momento }\end{array}$ & $\begin{array}{c}\text { Prevê o ensino fundamental, obrigatório e } \\
\text { gratuito, inclusive para os que a ele não } \\
\text { tiveram acesso na idade própria; } \\
\text { Prevê a progressiva extensão da } \\
\text { obrigatoriedade e gratuidade ao Ensino } \\
\text { Médio e prevê a titularidade do Estado na } \\
\text { oferta e a titularidade dos pais na matrícula } \\
\text { dos filhos }\end{array}$ & ----- \\
\hline $\begin{array}{c}\text { LDBEN } \\
9.394 / 1996\end{array}$ & Redemocratização & $\begin{array}{l}1996- \\
24 \text { anos até } \\
\text { o presente } \\
\text { momento }\end{array}$ & $\begin{array}{l}\text { Prevê o Ensino Fundamental obrigatório a } \\
\qquad \text { partir dos } 7 \\
\text { Apresenta o conceito de Educação Básica } \\
\text { composta pela Educação Infantil, Ensino } \\
\text { Fundamental e Ensino Médio } \\
\text { Prevê a titularidade do Estado na oferta e a } \\
\text { titularidade dos pais na matrícula dos } \\
\text { filhos }\end{array}$ & 8 anos \\
\hline $\begin{array}{c}\text { Lei } \\
9.424 / 1996\end{array}$ & Redemocratização & $\begin{array}{c}1996-2007 \\
11 \text { anos }\end{array}$ & $\begin{array}{c}\text { Cria o Fundo de Manutenção e } \\
\text { Desenvolvimento do Ensino Fundamental } \\
\text { e de Valorização do Magistério } \\
\text { (FUNDEF) }\end{array}$ & ----- \\
\hline $\begin{array}{c}\text { Lei } \\
11.494 / 2007\end{array}$ & Redemocratização & $\begin{array}{l}2007- \\
13 \text { anos até } \\
\text { o presente } \\
\text { momento }\end{array}$ & $\begin{array}{c}\text { Cria o Fundo de Manutenção e } \\
\text { Desenvolvimento da Educação Básica e } \\
\text { Valorização dos Profissionais da Educação } \\
\text { (FUNDEB) }\end{array}$ & ----- \\
\hline $\begin{array}{c}\text { Lei } \\
11.274 / 2006\end{array}$ & Redemocratização & $\begin{array}{l}2006- \\
14 \text { anos até } \\
\text { o presente } \\
\text { momento }\end{array}$ & $\begin{array}{l}\text { Prevê a obrigatoriedade do ensino } \\
\text { fundamental a partir dos } 6 \text { anos } \\
\text { Prevê a titularidade do Estado na oferta e a } \\
\text { titularidade dos pais na matrícula dos } \\
\text { filhos }\end{array}$ & 9 anos \\
\hline EC 59/2009 & Redemocratização & $\begin{array}{l}2009- \\
11 \text { anos até } \\
\text { o presente } \\
\text { momento }\end{array}$ & $\begin{array}{l}\text { Prevê a obrigatoriedade e gratuidade da } \\
\text { educação a partir do corte etário dos } 4 \text { aos } \\
\qquad 17 \text { anos } \\
\text { Prevê a titularidade do Estado na oferta e a } \\
\text { titularidade dos pais na matrícula dos } \\
\text { filhos }\end{array}$ & 14 anos \\
\hline
\end{tabular}

FONTE: Adaptado e ampliado de Nogueira (2012, grifo nosso). 
Embora o ordenamento jurídico avance na declaração do direito à educação, especialmente a partir do contexto de redemocratização nosso país possui cerca de 1,9 milhões ${ }^{22}$ crianças e jovens $^{23}$ fora da escola. (PNAD, 2017).

Além disso, não é possível simplesmente desconsiderar que a democratização do acesso à educação formal obrigatória “"[...] gerou obstáculos relativos ao prosseguimento dos estudos desses novos usuários da escola pública, visto que não tinham as mesmas experiências culturais dos grupos que tinham acesso à escola anteriormente [...]". (OLIVEIRA; ARAÚJO, 2005, p. 28).

O cenário educacional brasileiro, portanto, evidencia a necessidade da busca pela garantia do direito à educação em seu sentido amplo prevendo tanto a garantia do acesso, quanto a garantia da permanência e da conclusão com qualidade e para todos.

\section{CONSIDERAÇÕES FINAIS}

Do estudo empreendido é possível constatar que as constituições federais e legislações decorrentes destas, revelam-se como um retrato do seu tempo, evidenciando que a educação no Brasil se consolidou a partir da histórica negação do direito, já que o país passou mais tempo negando este direito e/ou o restringindo-o à determinadas pessoas e classes do que o declarando como direito universal.

Além disso, nos diferentes períodos históricos vividos pelo Brasil, desde o Império até os tempos atuais, é possível constatar que a democracia enquanto base fundante do Estado de Direito sempre foi um conceito caro para o povo brasileiro. O Brasil viveu mais tempo em governos não democráticos (imperial/governo monárquico, republicano/governo oligárquico, republicano/ilegítimo) do que em democracia propriamente, o que revela sua frágil consolidação, e, portanto, revela a importância fundamental em torno da constante vigília e luta por sua manutenção.

\footnotetext{
22 Dados publicados no ano de 2017.

${ }^{23}$ Crianças e jovens na grande maioria pobres, negros, indígenas e quilombolas e com marcadas diferenças regionais, de raça e de gênero.
} 


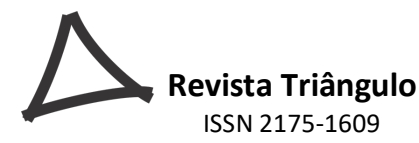

Por meio do quadro desvelado neste estudo é possível concluir que a democracia é o fundamento para a declaração e efetivação do direito à educação enquanto direito social e para todos, e, que dialeticamente, a garantia do direito à educação é o fundamento para a manutenção da democracia e do exercício dos direitos políticos de forma qualificada, ou seja, a democracia é o fundamento do direito à educação e o direito à educação é o fundamento da democracia.

Fica evidente, neste sentido, que embora a educação seja reconhecida como basilar para o desenvolvimento da sociedade e da democracia, a educação preconizada legalmente pelo Estado, historicamente esteve restrita ao ensino elementar (primário/fundamental), considerado como àquele indispensável para o exercício político, porém, precário para permitir questionar e/ou olhar criticamente para a realidade social, econômica, política e educacional constituída.

O Brasil sequer conseguiu garantir a universalização da Educação Básica possuindo milhares de crianças e jovens fora da escola e o Ensino Superior continua constitucionalmente fundamentado nas questões de mérito prevendo que o “[...] acesso aos níveis mais elevados do ensino, da pesquisa e da criação artística" ocorre em nosso país "segundo a capacidade de cada um.” (BRASIL, CF, 1988, não paginado).

No Brasil, a busca pela consolidação da democracia e do reconhecimento da educação como um direito só vai ter seu quadro modificado a partir da promulgação da Constituição Federal de 1988 a qual passa a qualificar a educação como um direito público subjetivo passível de exigibilidade e como um direito social a partir do direito-dever. Estabelecendo a titularidade do Estado em ofertar a educação obrigatória e gratuita e a responsabilidade da família em matricular os portadores de direito.

Após a CF de 1988 a LDBEN 9.394/1996 avança ao prever o conceito de Educação Básica (Educação Infantil, o Ensino Fundamental e o Ensino Médio) a partir de sua característica básica, comum e para todos e se adensa do ponto da declaração do direito a partir da criação dos fundos direcionados para o financiamento da educação.

Importa reiterar que embora o financiamento caracterize-se como um importante fator para a garantia do direito à educação, o mesmo ocorre muito tardiamente no Brasil. $\mathrm{O}$ financiamento do Ensino Fundamental começa a ocorrer somente a partir de 1996 e o financiamento da Educação Básica somente a partir do ano de 2007.

Os preceitos legais em torno da declaração do direito à educação se tornam mais potentes legalmente a partir da aprovação da EC 59/2009, a qual dentre outros preceitos constitucionais, prevê a ampliação da educação obrigatória dos 4 aos 17 anos e a ampliação do atendimento dos 
programas suplementares para toda a Educação Básica ressignificando a declaração e implementação do direito à educação enquanto direito social no país.

Embora a EC 59/2009 tenha aumentado o tempo de educação formal obrigatória de 9 para 14 anos, contraditoriamente, o faz colocando a centralidade da norma na faixa etária e não na etapa de ensino. Neste sentido, apesar do avanço na declaração do direito, o estabelecimento do corte etário, do ponto de vista da declaração do direito, desconsidera a construção do conceito (e do direito) da Educação Básica enquanto educação de base trazido pela LDBEN 9.394/1996.

A última vez que o país viveu a declaração do direito à educação a partir da faixa etária foi no contexto da ditadura civil-militar. Entende-se que considerando-se as desigualdades vividas pelo país no que tange ao processo de garantia da educação enquanto um direito social e para todos e da histórica negação do direito vivida pelas etapas da Educação Infantil e do Ensino Médio em detrimento do Ensino Fundamental, o mais viável seria prever a obrigatoriedade de todas as etapas de ensino, fortalecendo a Educação Básica como um conceito e como um direito ao torná-la um preceito constitucional.

Por fim, importa destacar que mesmo reconhecendo os desafios apresentados para a declaração e implementação do direito à educação no país, a declaração do direito enquanto força normativa é o primeiro caminho para fazê-lo, especialmente no Brasil, um país marcado pelas desigualdades sociais.

\section{REFERÊNCIAS}

ABREU, Daniela Cristina Lopes de. A escolarização dos negros e suas fontes de pesquisa. Revista HISTEDBR On-line, Campinas, n.42, p. 235-248, jun2011. Disponível em: http://www.histedbr.fe.unicamp.br/revista/edicoes/42/art15 42.pdf

ARANHA, Maria Lúcia de Arruda. História da educação e da pedagogia: geral e Brasil. São Paulo: Moderna, 2006.

AZEVEDO, Fernando de [et al.]. Manifestos dos pioneiros da Educação Nova (1932) e dos educadores 1959. Recife: Fundação Joaquim Nabuco, Editora Massangana, 2010. 
BARBOSA, ANA MAE. Arte-Educação no Brasil. Realidade Hoje e Expectativas Futuras. Scielo. Tradução Sofia Fan. 1989. Disponível em:

http://www.scielo.br/pdf/ea/v3n7/v3n7a10.pdf

BECKLES, Hilary Mcdonald. Slave Voyages: The Transatlantic Trade Enslaved Africans. Paris: UNESCO, 2003. Disponível em: https://unesdoc.unesco.org/ark:/48223/pf0000128631

BRASIL. Constituição Politica do Imperio do Brazil. Carta de Lei de 25 de Março de 1824. Manda observar a Constituição Politica do Imperio, oferecida e jurada por Sua Magestade o Imperador. Secretaria de Estado dos Negocios do Imperio do Brazil a fls. 17 do Liv. $4{ }^{\circ}$ de Leis, Alvarás e Cartas Imperiais. Disponível em:

http://www.planalto.gov.br/ccivil_03/constituicao/constituicao24.htm

BRASIL. Lei de 15 de outubro de 1827. Manda crear escolas de primeiras letras em todas as cidades, villas e logares mais populosos do Imperio. Coleção de Leis do Império do Brasil 1827, Página 71 Vol. 1 pt. I (Publicação Original). Disponível em:

https://www2.camara.leg.br/legin/fed/lei_sn/1824-1899/lei-38398-15-outubro-1827-566692publicacaooriginal-90222-pl.html

BRASIL. Constituição da República dos Estados Unidos do Brasil, de 24 de fevereiro de 1891. Nós, os representantes do povo brasileiro, reunidos em Congresso Constituinte, para organizar um regime livre e democrático, estabelecemos, decretamos e promulgamos a seguinte. Presidência da República. Casa Civil. Subchefia para Assuntos Jurídicos.

Disponível em: http://www.planalto.gov.br/ccivil 03/constituicao/constituicao91.htm

BRASIL. Constituição da República dos Estados Unidos do Brasil, de 16 de julho de 1934. Nós, os representantes do povo brasileiro, pondo a nossa confiança em Deus, reunidos em Assembleia Nacional Constituinte para organizar um regime democrático, que assegure à Nação a unidade, a liberdade, a justiça e o bem-estar social e econômico, decretamos e promulgamos a seguinte. Presidência da República. Casa Civil. Subchefia para Assuntos Jurídicos. Disponível em:

http://www.planalto.gov.br/ccivil_03/constituicao/constituicao34.htm

BRASIL. Constituição dos Estados Unidos do Brasil, de 10 de novembro de 1937. Leis Constitucionais. Presidência da República. Casa Civil. Subchefia para Assuntos Jurídicos. Disponível em: http:// http://www.planalto.gov.br/ccivil 03/constituicao/constituicao37.htm

BRASIL. Decreto-lei n. 4.244 de 9 de abril de 1942. Lei orgânica do ensino secundário. Senado Federal. Subsecretaria de Informações. Disponível em: http://www.histedbr.fe.unicamp.br/navegando/fontes_escritas/5_Gov_Vargas/decretolei\%204.244-1942\%20reforma\%20capanema-ensino\%20secund\%E1rio.htm

BRASIL. Constituição dos Estados Unidos do Brasil, de 18 de setembro de 1946. Presidência da República. Casa Civil. Subchefia para Assuntos Jurídicos. Disponível em: http://www.planalto.gov.br/ccivil 03/constituicao/constituicao46.htm 
BRASIL. Constituição da República Federativa do Brasil, de 24 de janeiro de 1967. Presidência da República. Casa Civil. Subchefia para Assuntos Jurídicos. Disponível em: http://www.planalto.gov.br/ccivil_03/constituicao/constituicao67.htm

BRASIL. Emenda Constitucional n. 1, de 17 de outubro de 1969. Edita o novo texto da constituição Federal de 24 de janeiro de 1967. Presidência da República. Casa Civil. Subchefia para Assuntos Jurídicos. Disponível em:

http://www.planalto.gov.br/ccivil_03/Constituicao/Emendas/Emc_anterior1988/emc01$\underline{69 . h t m}$

BRASIL. Constituição da República Federativa do Brasil, de 05 de outubro de 1988. Presidência da República. Casa Civil. Subchefia para Assuntos Jurídicos. Disponível em: www.planalto.gov.br/ccivil_03/constituicao/constituicaocompilado.htm

BRASIL. Lei n. 4.024, de 20 de dezembro de 1961. Fixa as Diretrizes e Bases da Educação Nacional. Presidência da República. Casa Civil. Subchefia para Assuntos Jurídicos. Disponível em: http://www.planalto.gov.br/ccivil 03/leis/L4024.htm

BRASIL. Lei n. 5.537 de 21 de novembro de 1968. Cria o Instituto Nacional de Desenvolvimento da Educação e Pesquisa (INDEP) e dá outras providências. Presidência da República. Casa Civil. Subchefia para Assuntos Jurídicos. Disponível em: http://www.planalto.gov.br/ccivil_03/LEIS/L5537.htm

BRASIL. Lei n. 5.692, de 11 de agosto de 1971. Fixa Diretrizes e Bases para o ensino de $1 .^{\circ}$ e 2..$^{\circ}$ graus, e dá outras providências. Presidência da República. Casa Civil. Subchefia para Assuntos Jurídicos. Disponível em: http://www.planalto.gov.br/ccivil_03/leis/L5692.htm

BRASIL. Lei n. 8.069, de 13 de julho de 1990. Dispõe sobre o Estatuto da Criança e do Adolescente e dá outras providências. Presidência da República. Casa Civil. Subchefia para Assuntos Jurídicos. Disponível em: http://www.planalto.gov.br/ccivil_03/leis/L8069.htm BRASIL. Lei n. 9.394, de 20 de dezembro de 1996. Estabelece as diretrizes e bases da educação nacional. Presidência da República. Casa Civil. Subchefia para Assuntos Jurídicos. Disponível em: http://www.planalto.gov.br/ccivil_03/leis/L9394.htm

BRASIL. Lei n. 9.424, de 24 de dezembro de 1996. Dispõe sobre o Fundo de Manutenção e Desenvolvimento do Ensino Fundamental e de Valorização do Magistério, na forma prevista no art. $60, \S 7^{\circ}$, do Ato das Disposições Constitucionais Transitórias, e dá outras providências. Presidência da República. Casa Civil. Subchefia para Assuntos Jurídicos. Disponível em: http://www.planalto.gov.br/ccivil_03/LEIS/L9424compilado.htm

BRASIL. Lei n. 11.494, de 20 de junho de 2007. Regulamenta o Fundo de Manutenção e Desenvolvimento da Educação Básica e de Valorização dos Profissionais da Educação FUNDEB, de que trata o art. 60 do Ato das Disposições Constitucionais Transitórias; altera a Lei n o 10.195, de 14 de fevereiro de 2001; revoga dispositivos das Leis n os 9.424, de 24 de dezembro de 1996, 10.880, de 9 de junho de 2004, e 10.845, de 5 de março de 2004; e dá outras providências. Presidência da República. Casa Civil. Subchefia para Assuntos Jurídicos. Disponível em: http://www.planalto.gov.br/ccivil 03/_ato20072010/2007/lei/111494.htm 
BRASIL. Emenda Constitucional n. 59, de 11 de novembro de 2009. Emenda Constitucional $\mathrm{n}^{\circ}$ 59, de 11 de novembro de 2009. Acrescenta $\S 3^{\circ}$ ao art. 76 do Ato das Disposições Constitucionais Transitórias para reduzir, anualmente, a partir do exercício de 2009, o percentual da Desvinculação das Receitas da União incidente sobre os recursos destinados à manutenção e desenvolvimento do ensino de que trata o art. 212 da Constituição Federal, dá nova redação aos incisos I e VII do art. 208, de forma a prever a obrigatoriedade do ensino de quatro a dezessete anos e ampliar a abrangência dos programas suplementares para todas as etapas da educação básica, e dá nova redação ao $\S 4^{\circ}$ do art. 211 e ao $\S 3^{\circ}$ do art. 212 e ao caput do art. 214 , com a inserção neste dispositivo de inciso VI. Diário Oficial da União. Presidência da República. Casa Civil. Subchefia para assuntos jurídicos. Disponível em:

http://www.planalto.gov.br/ccivil_03/Constituicao/Emendas/Emc/emc59.htm

CELLARD, André. A análise documental. In: POUPART, Jean. Et. al. A pesquisa qualitativa: enfoques epistemológicos e metodológicos. Petrópolis: Vozes, 2008.

COSTA, Messias. A educação nas constituições do Brasil: dados e direções. Rio de Janeiro: DP \& A, 2002.

CUNHA, Luiz Antônio. O legado da ditadura para a educação brasileira. Educ. Soc., Campinas, v. 35, n. 127, p. 357-377, abr.-jun. 2014. Disponível em:

http://www.cedes.unicamp.br

CURY, Roberto Jamil. A Educação Básica no Brasil. Educação \& Sociedade, Campinas, v. 23, n. 80, p. 169-201, set. 2002. Disponível em:

http://www.scielo.br/scielo.php?pid=S01013302002008000010\&script $=$ sci_abstract\&tlng $=\mathrm{pt}$

CURY, Roberto Jamil. Direito à educação: Direito à Igualdade, Direito à Diferença.

Cadernos de Pesquisa, n. 116, julho/ 2002a. Disponível em:

http://www.scielo.br/pdf/cp/n116/14405.pdf

CURY, Roberto Jamil. A Educação Básica como Direito. Cadernos de Pesquisa, v. 38, n. 134, p. 293-303, maio/ago. 2008. Disponível em:

www.scielo.br/pdf/cp/v38n134/a0238134.pdf

CURY, Carlos Roberto Jamil; FERREIRA, Luiz Antonio Miguel. Obrigatoriedade da educação das crianças e adolescentes: uma questão de oferta ou de efetivo atendimento? Nuances: estudos sobre Educação. Ano XVII, v. 17, n. 18, p. 124-145, jan./dez. 2010. Disponível em: http://revista.fct.unesp.br/index.php/Nuances/article/view/729/741

DALLABRIDA, Norberto. A reforma Francisco Campos e a modernização nacionalizada do ensino secundário. Educação, Porto Alegre, v. 32, n. 2, p. 185-191, maio/ago. 2009.

Disponível em:

http://revistaseletronicas.pucrs.br/ojs/index.php/faced/article/viewFile/5520/4015 
DALLABRIDA, Norberto. O MEC-INEP contra a Reforma Capanema: renovação do ensino secundário na década de 1950. PERSPECTIVA, Florianópolis, v. 32, n. 2, 407-427, maio/ago. 2014. Disponível em:

https://periodicos.ufsc.br/index.php/perspectiva/article/viewFile/2175795X.2014v32n2p407/29711

DINIZ, Eli. Engenharia institucional e políticas públicas: dos conselhos técnicos às câmaras setoriais. In: PANDOLFI, Dulce. (Org.) Repensando o Estado Novo. Rio de Janeiro: Ed. Fundação Getulio Vargas, 1999. Disponível em: https://cpdoc.fgv.br/producao_intelectual/arq/142.pdf

FÁVERO, Osmar. A Educação no Congresso Constituinte 1966-67: contrapontos. In: FÁVERO, Osmar (Org.). A Educação nas Constituintes Brasileiras 1823-1988. 2. ed. Campinas: Autores Associados. 2001.

FERNANDES, Florestan. Entrevista a Transformação, n. ${ }^{\circ}$ 2, 1975. Disponível em: http://www2.marilia.unesp.br/revistas/index.php/transformacao/article/view/1060

FERRARO, Alceu Ravanello. Direito à educação no Brasil e dívida educacional: e se o povo cobrasse? Educação e Pesquisa, São Paulo, v.34, n.2, p. 273-289, maio/ago. 2008.

Disponível em: http://www.scielo.br/pdf/ep/v34n2/05.pdf

FLACH, Simone de Fátima. O direito à educação e sua relação com a ampliação da escolaridade obrigatória no Brasil. Ensaio: aval. pol. públ. Educ., Rio de Janeiro, v. 17, n. 64, p. 495-520, jul./set. 2009. Disponível em:

www.scielo.br/pdf/ensaio/v17n64/v17n64a06.pdf

FRIGOTTO, Gaudêncio, CIAVATTA, Maria, RAMOS, Marise. A gênese do Decreto n. 5.154/2004 um debate no contexto controverso da democracia restrita. Ano 3, número 3, 2005. Disponível em:

http://forumeja.org.br/pf/sites/forumeja.org.br.pf/files/CIAVATTAFRIGOTTORAMOS.pdf

GOMES, Candido Alberto da Costa. (Org.). O Ensino Médio no Brasil: ou a história do patinho feio recontada. Brasília: Universa, 2000.

GROFF, Paulo Vargas. Direitos Fundamentais nas Constituições brasileiras. Brasília a. 45 n. 178 abr./jun. 2008. Disponível em:

https://www2.senado.leg.br/bdsf/bitstream/handle/id/176526/000842780.pdf?sequence=3\&is Allowed $=\mathrm{y}$

MEZZAROBA, Orides; CASTRO, Matheus Felipe de. História do Direito Constitucional Brasileiro: a Constituição do Império do Brasil de 1824 e o sistema privado escravocrata. Revista Brasileira de Direito, v. 13, n. 2, 2017. Disponível em: https://seer.imed.edu.br/index.php/revistadedireito/rt/printerFriendly/1894/1212 1/

MARCONI, Marina de Andrade; LAKATOS, Eva Maria. Técnicas de Pesquisa. São Paulo: Atlas, 1999. 
NOGUEIRA, Octaciano. Constituição 1824. Coleção Constituições brasileiras: v. 1, 3. ed. Brasília: Senado Federal, Subsecretaria de Edições Técnicas, 2012. Disponível em: https://www2.senado.leg.br/bdsf/bitstream/handle/id/137569/Constituicoes_Brasileiras_v1_1 824.pdf

OLIVEIRA, Romualdo Portela; ARAUJO, Gilda Cardoso. Qualidade do ensino: uma nova dimensão da luta pelo direito à educação. Rev. Bras. Educ. n.28. Rio de Janeiro Jan./Abr. 2005. Disponível em: http://www.scielo.br/pdf/rbedu/n28/a02n28.pdf

PANDOLFI, Dulce. (Org.) Repensando o Estado Novo. Rio de Janeiro: Ed. Fundação Getulio Vargas, 1999. Disponível em: https://cpdoc.fgv.br/producao intelectual/arq/142.pdf

PORTO, Walter Costa. Constituições Brasileiras. 1937. Brasília: Senado Federal, Secretaria Especial de Editoração e Publicações. Subsecretaria de Edições Técnicas, 2012. Disponível em:

https://www2.senado.leg.br/bdsf/bitstream/handle/id/137571/Constituicoes_Brasileiras_v4_1 937.pdf? sequence $=9$

PNAD. Pesquisa Nacional por Amostra de Domicílios Contínua - 2017. Disponível em: https://www.ibge.gov.br/estatisticas/multidominio/condicoes-de-vida-desigualdade-e-pobreza/17270pnad-continua.html? edicao $=21073 \& \mathrm{t}=$ sobre

SANTOS, Cristina Jesus dos. Os artistas em tempos de Estado Novo: Trabalhismo e Associativismo na Sociedade Montepio dos Artistas de Itabuna (1937-1945). XXIX Simpósio de História Nacional: Contra os preconceitos, História e Democracia. Disponível em: https://www.snh2017.anpuh.org/resources/anais/54/1502847759_ARQUIVO_Osartistasemte mposdeEstadoNovo.pdf

SAVIANI, Dermeval. O Legado educacional do regime militar. Cad. Cedes, Campinas, vol. 28, n. 76, p. 291-312, set./dez. 2008. Disponível em:

http://www.scielo.br/pdf/ccedes/v28n76/a02v2876.pdf

SILVA, Rafael Trindade da; SOUZA, Maria Aparecida Silva de. Nação e Liberalismo na Constituição Brasileira de 1891. XII Colóquio Nacional e V Colóquio Internacional do Museu Pedagógico. 26 a 29 de setembro de 2017. Disponível em: www.periodicos.uesb.br/index.php/cmp/article/view/7086/pdf_ 778

STAMATTO. Maria Inês Sucupira. Um olhar na história: a mulher na escola Brasil:15491910. ) SBHE - Sociedade Brasileira de Educaçãa. II Congresso brasileiro de História e educação. Relações de gênero e educação brasileira. Natal: 2002. Disponível em: http://www.sbhe.org.br/novo/congressos/cbhe2/pdfs/Tema5/0539.pdf

VAINER, Bruno Zilberman. Breve histórico acerca das constituições do Brasil e do controle de constitucionalidade brasileiro. Revista Brasileira de Direito Constitucional - RBDC, n. 16 - jul./dez. 2010. 
Disponível em: http://www.esdc.com.br/RBDC/RBDC-16/RBDC-16-161-

Artigo_Bruno_Zilberman_Vainer_Breve_Historico_acerca_das_Constituicoes_do_Brasil_e do_Controle_de_Constitucionalidade_Brasileiro).pdf

VIEIRA, Sofia Lerche. A educação nas constituições brasileiras: texto e contexto. R. bras. Est. pedag., Brasília, v. 88, n. 219, p. 291-309, maio/ago. 2007. Disponível em:

http://www.ia.ufrrj.br/ppgea/conteudo/conteudo-2010-

1/3SF/VIEIRA,SofiaEducacaonasconstituicoes,2007.pdf

VIEIRA, Sofia Lerche; VIDAL, Eloísa Maia. Política de financiamento da educação no Brasil: uma (re)construção histórica. Em Aberto, Brasília, v. 28, n. 93, p. 17-42, jan./jun. 2015. Disponível em:

http://portal.inep.gov.br/documents/186968/485895/O+Fundeb+em+perspectiva/e04c88f953d2-4f9b-9e80-1277fac4e516? version $=1.3$ 